\title{
MODIS-Based Investigation of Flood Areas in Southern Cambodia from 2002-2013
}

\author{
Nguon Vichet ${ }^{1,2}$, Kensuke Kawamura ${ }^{3, *(0)}$, Dung Phan Trong ${ }^{2,4}$, Nguyen Van On ${ }^{2,5}$, \\ Zhe Gong ${ }^{2}$, Jihyun Lim ${ }^{2,6}$, Sok Khom ${ }^{1}$ and Chhun Bunly ${ }^{7}$ \\ 1 Cambodia National Mekong Committee (CNMC), 576 National Road, No. 2, Sangkat Chak Angre krom, \\ Khan Meanchey, Phnom Penh 12353, Cambodia; vichetnvt@gmail.com (N.V.); skom.sk@gmail.com (S.K.) \\ 2 Graduate School for International Development and Cooperation (IDEC), Hiroshima University, \\ 1-5-1 Kagamiyama, Higashi-Hiroshima, Hiroshima 739-8529, Japan; phandungvqh@gmail.com (D.P.T.); \\ onnv@vfu.edu.vn (N.V.O.); gongzhe79@126.com (Z.G.); j_lim@affrc.go.jp (J.L.) \\ 3 Japan International Research Center for Agricultural Sciences (JIRCAS), 1-1 Ohwashi, Tsukuba, \\ Ibaraki 305-8686, Japan \\ 4 Department of Strategy Development for Urban and Rural zone, Hanoi Urban Planning \\ Institute (HUPI)-Hanoi People's Committee (HPC), Nguyen Chanh Street, Trung Hoa Ward, \\ Hanoi 100000, Vietnam \\ 5 College of Landscape and Interior Design, Vietnam National University of Forestry (VNUF), Xuan Mai, \\ Chuong My, Hanoi 100000, Vietnam \\ 6 National Agriculture and Food Research Organization (NARO), Western Region Agricultural Research \\ Center, Ohda, Shimane 694-0013, Japan \\ 7 Ministry of Environment (MoE), Preah Sihanouk Blvd, Tonle Bassak, Chamkamorn, \\ Phnom Penh 120101, Cambodia; chhunbunly@gmail.com \\ * Correspondence: kamuken@affrc.go.jp; Tel.: +81-298-386-628
}

Received: 25 April 2019; Accepted: 22 May 2019; Published: 25 May 2019

\begin{abstract}
In Cambodia and the Vietnamese Mekong Delta, floods commonly occur during the rainy season, and a better understanding of their spatio-temporal distribution is important for both disaster prevention and the improvement of agricultural production. This study investigated spatio-temporal flood inundation and land cover change from 2002 to 2013 in the southern part of Cambodia using Terra satellite on-board Moderate Resolution Imaging Spectroradiometer (MODIS) images. The algorithm for flood inundation detection, WFFI (Wavelet-based Filter for detecting spatio-temporal changes in Flood Inundation) was used, and the parameters were modified to fit the present study. The estimated inundation areas were validated using eight Landsat images. In a comparison between the original and modified WFFIs, the modified WFFI (70-96\%) exhibited better accuracy than the original WFFI (30-70\%). Overall, the temporal change in the flood inundation area presented a decreasing trend, and a link to the in-situ observed water level showed a decreasing trend during the rainy season. Furthermore, the estimated flood inundation exhibited a significant delay since 2008. Based on the yearly land cover MODIS product, the permanent water body and wetland areas decreased, whereas the cropland areas increased. This was as a result of increased agricultural productivity. However, water shortage was the major obstacle to increasing agricultural productivity, and it also had a negative impact on aquatic ecology, such as fish spawning grounds.
\end{abstract}

Keywords: environmental monitoring; flooding; natural disaster; satellite remote sensing

\section{Introduction}

In Cambodia, as in the most of the countries along the Mekong River, which is the seventh longest river in Asia, floods commonly occur during the rainy season, and they have both beneficial and 
harmful effects. Flooding is the main natural disaster, followed by drought and, to a lesser extent, health epidemics and storms [1]. Meanwhile, annual flooding in the Mekong River basin provides vital resources to agro-ecosystems [2,3]. For example, floods improve the soil moisture and fertility of the soil [4] and also provide ecological benefits for fisheries [5].

Remote sensing is a promising tool for observing and understanding the spatial and temporal dynamics of floods. To date, numerous studies have been conducted using Synthetic Aperture Radar (SAR) and optical images to detect the spatial and temporal changes in the extent of flood inundation, including the delineation of wetlands [6-9]. SAR images can monitor ground surface data without cloud cover effects. They are very sensitive to water surface effects due to wind and currents. On the other hand, optical images are strongly disturbed by cloud cover but are less sensitive to surface features. Thus, optical images with high temporal resolution sensors are suited to monitoring water bodies. Based on the optical images, several methodologies have been developed to detect surface water bodies and flood areas in different areas of research such as crop productivity estimation in paddy fields [10,11], cropping systems identification [12,13], mapping inland aquaculture [14], habitat studies for fish and aquatic life [15] and flooded disaster zones [10].

The Moderate Resolution Imaging Spectroradiometer (MODIS) sensor on-board the Terra satellite is one of the most widely applied moderate-resolution optical sensor used to monitor inundation areas with high temporal resolution. The MODIS data are provided free of charge throughout the world from the Earth Observation System (EOS, http//:reverb.echo.nasa.gov). Using time-series MODIS data, Sakamoto et al. [16] developed an algorithm, "Wavelet-based Filter for detecting the spatio-temporal changes in Flood Inundation (WFFI)," specifically for Cambodia and Vietnam. The WFFI method includes a wavelet-based filter for the interpolation of missing data and noise reduction within temporal data. Using WFFI, Sakamoto et al. [16] determined the spatial characteristics of the estimated start dates, end dates, and duration of inundation cycles from 2000 to 2004 in Cambodia and Vietnam. Their results clearly indicated that the estimated area of long-term water body increased in size from 2000 to 2004, particularly in coastal areas of the Ca Mau and Bac Lieu province. Islam et al. [17] modified the WFFI for flood detection in Bangladesh by comparing it with RADARSAT images. Their results indicate that MODIS data with the WFFI method are very useful for detecting spatio-temporal flood inundation.

Water resource development in the Mekong basin will control annual flooding and reduce the inundation area. Understanding flood patterns and trends could be potentially useful for many reasons, such as the preparation of crop calendars and disaster management. In particular, the yields of an agricultural area may be determined by a decrease in water content. The spatial and temporal extent of flood inundation is important information for the evaluation of the relationships between the water regime and local agricultural activities. Furthermore, recent and rapid population growth and a lack of clear development plans, laws and regulations have resulted in uncontrolled changes in land use and land cover in the Phnom Penh city [18].

Therefore, this study investigated spatio-temporal flood inundation and land cover change during the period from 2002-2013 in the southern part of Cambodia, using time series MODIS data with the WFFI algorithm. In this study, the parameters of the WFFI algorithm have been adopted from Sakamoto et al. [16] due to updating of the MODIS surface reflectance products and the fact that the study area is on a provincial scale in Cambodia with the same characteristics. First, the spatio-temporal changes of a water body area were detected from a MODIS image using the modified WFFI. The water body detection methods were compared to the results using the original WFFI. The estimated inundation areas were validated using eight Landsat-derived inundation areas. Then, we assessed the yearly trends in seasonal changes of flooding areas and its relation to land cover changes.

\section{Study Area}

The study area is located in Southern Cambodia $\left(10^{\circ} 30^{\prime}-13^{\circ} 45^{\prime} \mathrm{N} ; 103^{\circ} 25^{\prime}-106^{\circ} 00^{\prime}\right.$ E) (Figure 1) and is approximately $28,800 \mathrm{~km}^{2}$; the Cambodian climate is tropical with two distinct seasons: Dry and rainy. The majority of the land area is at an elevation below $40 \mathrm{~m}$, which is vulnerable to flooding. 
Phnom Penh is the capital city, and three other provinces (Kampong Cham, Kandal and Prey Veng) are located in Southern Cambodia, along the Mekong River.
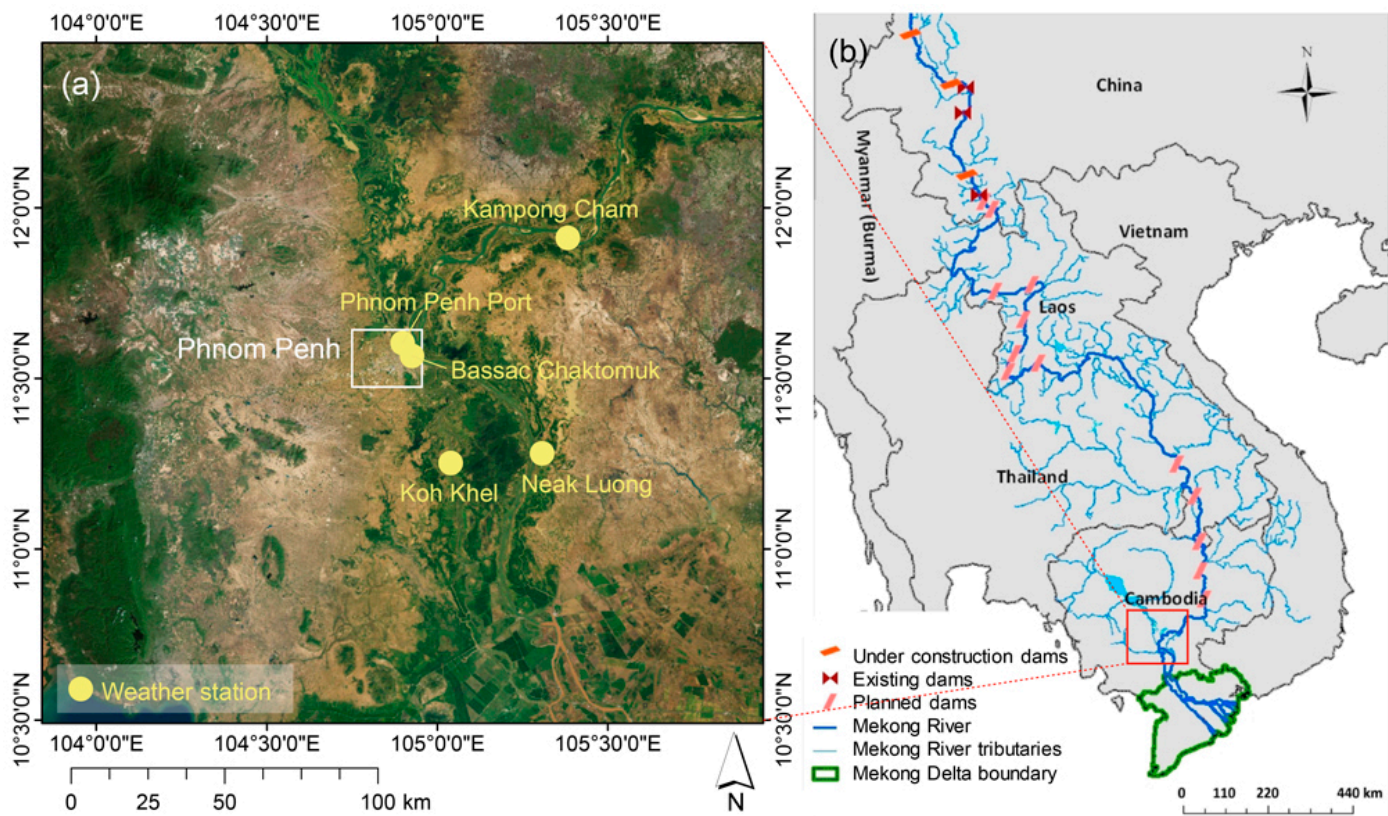

Figure 1. Location map of study area. (a) Satellite images of study area with locations of water station. Sources: Esri, DigitalGlobe, GeoEye, Earthstar Geographics, Centre National d'études Spatiales (CNES)/Airbus Defense and Security (DS), US Department of Agriculture (USDA), United States Geological Survey (USGS), AeroGRID, Institut Géographique National (IGN), and the GIS user community. (b) Location of study area with the Mekong River basin.

\section{Data Set}

\subsection{MODIS Data}

This study used the following two MODIS products: (1) The MODIS/Terra Surface Reflectance 8-Day L3 Global $500 \mathrm{~m}$ SIN Grid V005 (MOD09A1) and (2) The Land Cover Type Yearly L3 Global $500 \mathrm{~m}$ SIN Grid (MCD12Q1). The MOD09A1 products yield the best surface spectral-reflectance data over an 8-day period, with the least effects from atmospheric water vapor (EOS, 2014). This study involved an analysis of MOD09 8-day composite data acquired from 2002 (day of year (DOY) 1) to 2013 (DOY 365). The spatial distribution of the start dates varied year by year [16]. Although the level of cloud cover in the wet season means that it is difficult to obtain cloud-free images every day, 8-day composite products can provide an image that is almost free of clouds and that is atmospherically corrected. Although there is a limitation that spatial resolution becomes coarser than Landsat, the time series MODIS data could be used to determine these dates to the nearest week and to map the spatial extent of a flood.

The MCD12Q1 product is supplied annually, and it covers land areas with a $500 \mathrm{~m}$ spatial resolution. There are five classification schemes in this product that display land cover properties from observations, which include one year's input of Terra and Aqua MODIS data. In this study, we used the primary land cover scheme (17 land cover classes) defined by the International Geosphere Biosphere Program (IGBP), which includes 11 natural vegetation classes, three developed and mosaicked land classes, and three non-vegetated land classes.

The default projection of original MODIS data is a MODIS sinusoidal tiling system. After mosaicking six tiled images to cover the study area, all the data were transferred into the Geographic Tagged Image File Format (GeoTIFF) with geographic projection (Latitude/Longitude, WGS84) using the MODIS reprojection tool [19]. 


\subsection{Landsat Data}

Eight Landsat images (see Table 1) were downloaded from the Global Land Cover Facility GLCF [20]. In the study, five images were obtained from the Landsat 7 satellite on-board Enhanced Thematic Mapper plus (ETM+), and another three images were obtained by the Landsat 8 satellite on-board Operational Land Imager (OLI) within only one path/row (126/52). Atmospheric correction was performed using a Fast Line-of-sight Atmospheric Analysis of a Spectral Hypercube (FLAASH) module on ENVI software ver. 5.1 (Excelis Visual Information Solutions, Colorado, USA).

Table 1. Estimated accuracy of the WFFI product relative to the inundation area derived from Landsat images.

\begin{tabular}{cccc}
\hline \multirow{2}{*}{ Satellite/Sensor } & Date (Day of Year (DOY)) & \multicolumn{2}{c}{ Overall Accuracy (\%) } \\
\cline { 2 - 4 } & & Original WFFI & Modified WFFI \\
\hline Landsat 7/ETM+ & 3 January 2002 (003) & 30.61 & 82.11 \\
& 20 February 2002 (051) & 37.75 & 93.51 \\
& 8 March 2002 (067) & 40.66 & 93.80 \\
& 7 February 2003 (038) & 41.58 & 91.64 \\
Landsat 8 OLI & 12 April 2003 (102) & 41.93 & 95.39 \\
& 5 May 2013 (137) & 41.82 & 96.2 \\
& 14 October 2013 (297) & 70.23 & 70.12 \\
& 27 December 2013 (361) & 43.14 & 81.31 \\
\hline
\end{tabular}

\subsection{Daily Water Level}

Daily water level data between 2002 and 2013 from five stations were provided by the Mekong River Commission (MRC). The stations are located at Bassac Chaktomuk ( $11^{\circ} 33^{\prime} 7^{\prime \prime}$ E, $\left.104^{\circ} 55^{\prime} 59^{\prime \prime} \mathrm{N}\right)$,

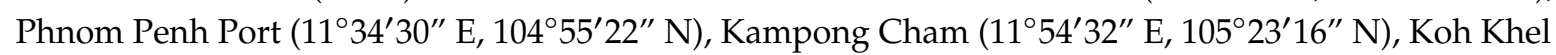
$\left(11^{\circ} 16^{\prime} 4^{\prime \prime} \mathrm{E}, 105^{\circ} 1^{\prime} 40^{\prime \prime} \mathrm{N}\right)$ and Neak Luong $\left(11^{\circ} 15^{\prime} 39^{\prime \prime} \mathrm{E}, 105^{\circ} 17^{\prime} 52^{\prime \prime} \mathrm{N}\right)$ (Figure 1a).

\section{Methods}

\subsection{Detecting Water Surface Using MODIS Data with WFFI}

The WFFI algorithm used in this study is a modified approach, as shown in Figure 2, based on the techniques originally developed by Sakamoto et al. [16] to detect spatio-temporal flood distributions in Cambodia and Vietnam. The WFFI is based on smoothed indices of MODIS images, including the Enhanced Vegetation Index (EVI), Land Surface Water Index (LSWI) and their difference (DVEL):

$$
\begin{gathered}
\mathrm{EVI}=2.5 \times \frac{N I R-\text { Red }}{\text { NIR }+6 \times \text { Red }-7.5 \times \text { Blue }+1}, \\
\mathrm{LSWI}=\frac{N I R-S W I R}{N I R+S W I R}, \\
\mathrm{DVEL}=\mathrm{EVI}-\mathrm{LSWI},
\end{gathered}
$$

where Blue, Red, NIR and SWIR are the surface reflectance value in blue (band 3; 459-479 nm), red (band 1; 621-670 nm), near infrared (NIR) (band 2; 841-875 nm) and short-wave infrared (SWIR) (band 6; 1628-1652 $\mathrm{nm}$ ), respectively.

In the original WFFI algorithm of MODIS sensor, a wavelet-based filter was used to interpolate any missing information. The production of the inundation maps involved a decision tree to classify each pixel into one of the following categories: flood, mixture, non-flood and a long-term water body. In the present study, the threshold values of the decision tree were modified based on the smoothed EVI, LSWI and DVEL values (Figure 3). The modified WFFI was evaluated by comparing it with the original WFFI. 


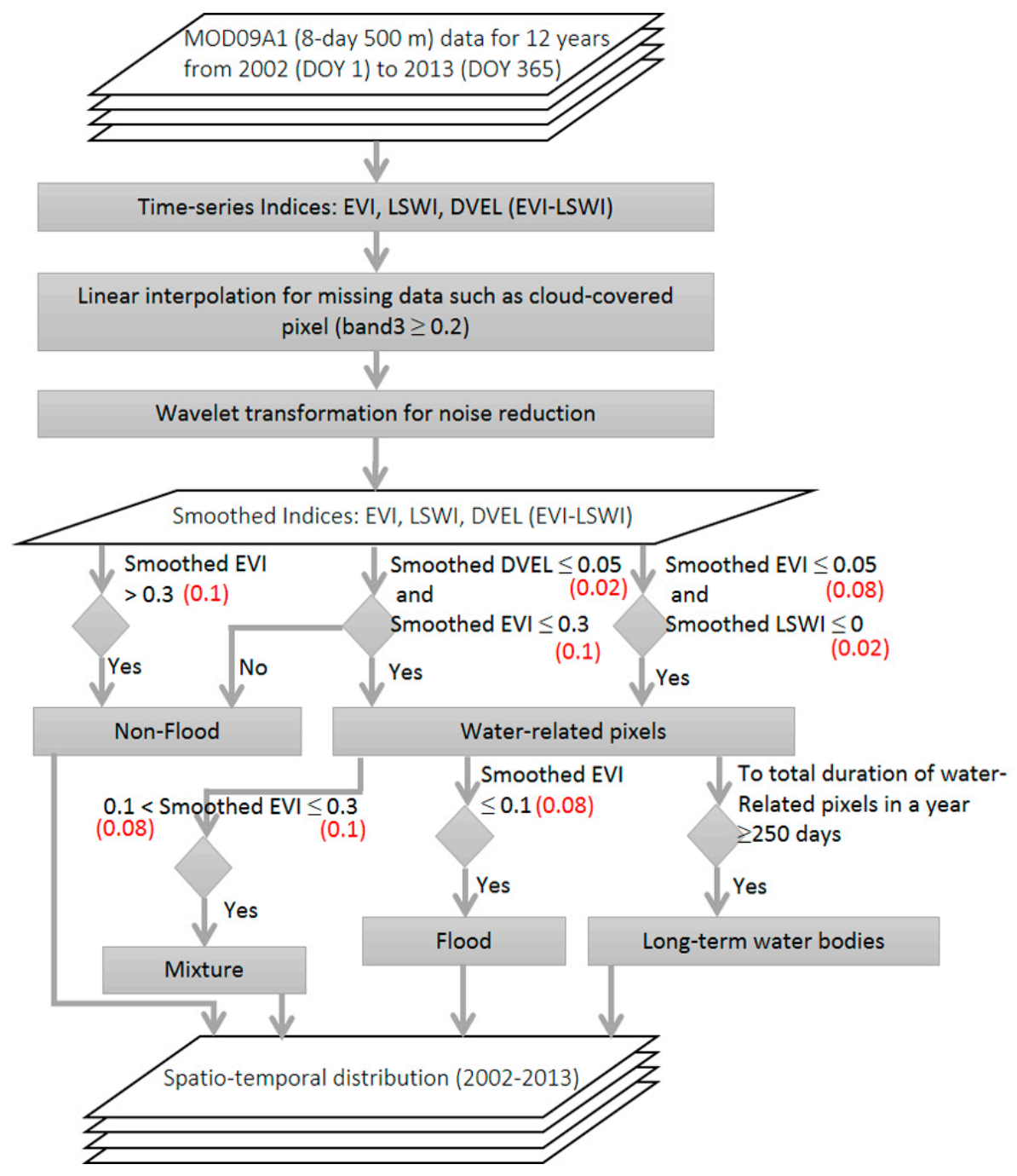

Figure 2. Flow chart of the mechanisms of the Wavelet-based Filter for detecting the spatio-temporal changes in Flood Inundation (WFFI), developed by Sakamoto et al. [16]. Red fonts indicate modified threshold values in this study. 

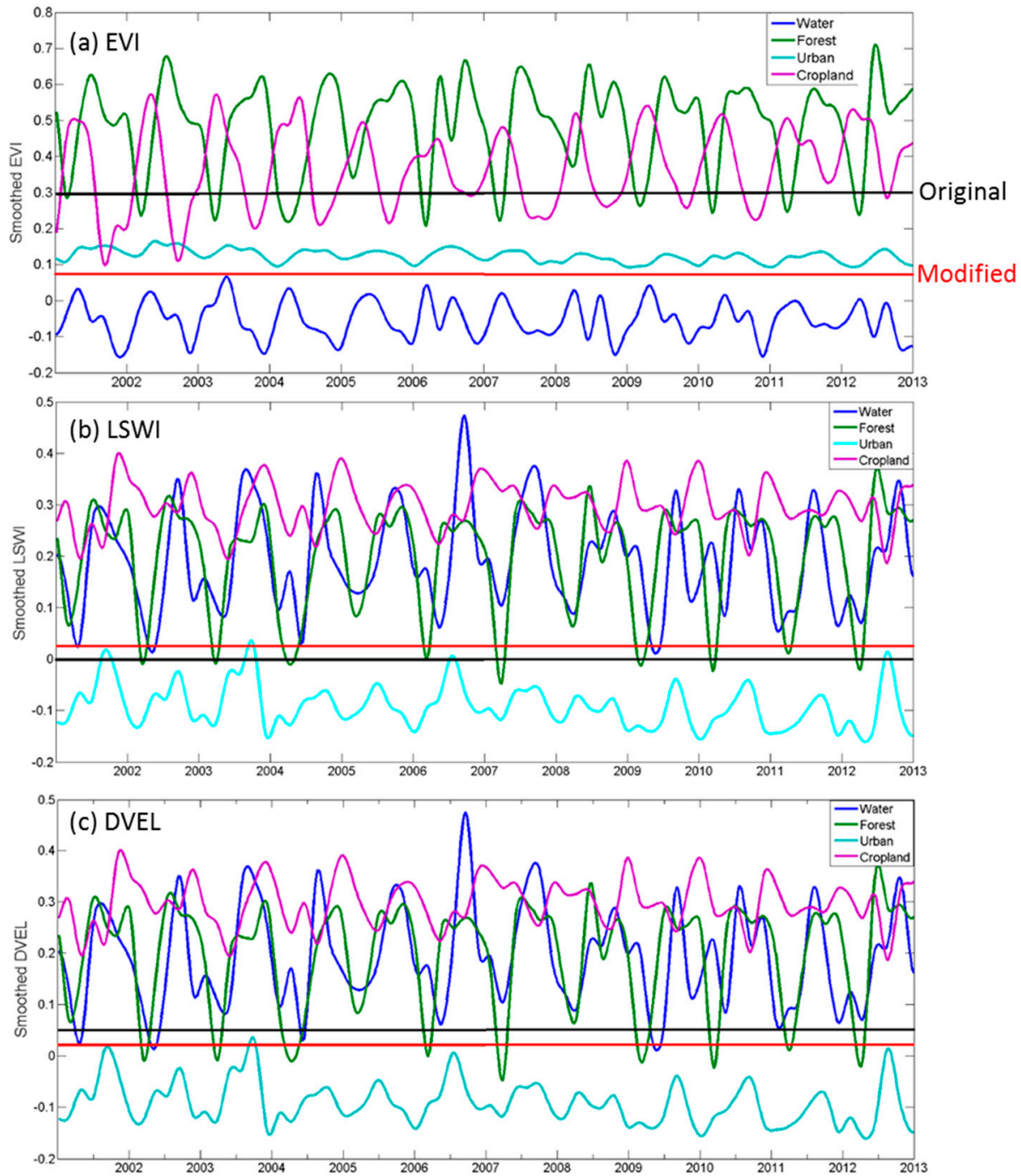

Figure 3. Smoothed (a) Enhanced Vegetation Index (EVI), (b) Land Surface Water Index (LSWI) and (c) difference between EVI and LSWI (DVEL) of four land cover types with threshold values in the original WFFI and modified WFFI (black and red line, respectively).

\subsection{Validation with Landsat Data}

Several studies have been conducted on detecting water bodies using Landsat data [21-25]. To detect water bodies from Landsat image, several band ratio indices have been developed. In this study, the water surface pixels were identified using the Modified Normalized Difference Water Index (MNDWI) [25] as a simple but more effective band ratio method than others. First, the non-analysis areas including cloud cover and cloud shadow were determined from the blue reflectance value. The cloud-cover areas were derived from the majority analysis (window size: $3 \times 3$ pixels) for pixels whose blue reflectance (band 1 in Landsat 7 ETM+ or band 2 in Landsat 8 OLI) was greater than 0.2 . The cloud-shadow areas were then masked by the cloud-cover areas, including 10-pixel buffer zones, where they were shifted in the opposite direction from the sun orientation. Next, water surface pixels were identified where the MNDWI was greater than or equal to 0 . The equation for the MNDWI used in this study is as follows [25],

$$
\text { MNDWI }=\frac{\text { Green }-M I R}{\text { Green }+ \text { MIR }}
$$

where Green and MIR are the surface reflectance values in green (band 2; 530-600 nm for Landsat 5, 530-610 $\mathrm{nm}$ for Landsat 7) and middle-infrared (MIR) (band 5; 1550-1750 nm) bands 
Lastly, 'not water-surface' pixels were identified where MNDWI was less than 0 . The threshold value of 0 was adopted from previous literature by Xue [25]. The land-surface map was resampled to a grid with a resolution of $25 \mathrm{~m}$ using the nearest neighbor method, and then the areas of these different land-surface types were aggregated within each grid with a resolution of $500 \mathrm{~m}$ to compare the MODIS-derived results.

\subsection{Start and End Dates of Flooding}

The continuous flood period was determined by the following procedures: (1) The continuous inundation period was recorded by water-related pixels (both flood and mixture pixels) and computed with water-related or non-flood pixels over 12 years; (2) if the periods of continuous inundation were identified twice or more in a year, the longer period was taken as the period of annual flood inundation; and (3) the duration of annual flood inundation was detected using the start and end dates of annual flood inundation.

\subsection{Water Level Trends}

The annual changes in water levels in the rainy season (June-November) were examined. According to the slope factor of the linear regression function, the trend in water level time-series data could be incorporated into the calculation; the slope of the linear regression model fit resembles a straight line, with the water level data plotted on the $y$-axis as the response variable and the value of time $(t=1,2,3, \ldots)$ plotted on the $x$-axis as an explanatory variable. Therefore, if the slope factor $\geq 0$, the water has increased or not changed, and if the slope factor $<0$, the water has decreased.

\section{Results}

\subsection{Detecting Flood Areas}

Figure 4 shows the surface water area derived by the modified WFFI and original WFFI on 1 January 2002. In the inundation map from the original WFFI, approximately $78 \%$ of the area is covered by water, suggesting overestimation. In a comparison between the original and modified WFFIs (see Table 1), the modified WFFI (70-96\%) exhibited better accuracy than the original WFFI (30-70\%). This might be considered to be differences in the sensitivity of the bands used for WFFI due to the change in MODIS product. The original WFFI was developed in version 4 of the MODIS product, while version 5 was used in this study, so it was necessary to adjust the threshold value for extracting water-related pixels in WFFI. This was in agreement with a previous study by Islam et al. [17] with MODIS product in version 5. They adopted and modified WFFI in Bangladesh to produce a flood inundation map and obtained similar accuracy $\left(R^{2}=0.96\right)$ in validation using the RADARSAT derived surface water area.

Spatial resolutions of $500 \mathrm{~m}$ could be another limitation in original WFFI, which are not always suited to small river catchments [26]. The threshold value in NDWI varies depending on the proportions of subpixel water or non-water components [27]. In this study, inundation maps derived from Landsat images, which was resampled in a resolution of $500 \mathrm{~m}$ to conform the MODIS-derived results were used for the validation. Better spatial resolution data, such as Landsat $(30 \mathrm{~m})$ or Sentinel-2 $(10 \mathrm{~m})$, could be reduced by the mixture issues, and provide more appropriate spatial information to water mapping applications [28-30]. However, their temporal frequency (revisit every 16 days in Landsat and 5 days in Sentinel-2) are not suited for monitoring spatial dynamics in flood events. Therefore, MODIS data is still used for mapping flood events due to the near-global spatial (250-1000 m) and high temporal (daily) characteristics.

Due to the limitation of field data, in this study, the validation was made by Landsat-derived results using MNDWI as the most suitable indices for detecting surface water [31]. To date, several indices have been developed to determine water-related pixels in optimal satellite data, such as normalized difference water index (NDWI) [32]. Future work needs to examine this by comparing other indices with field surveys data. 


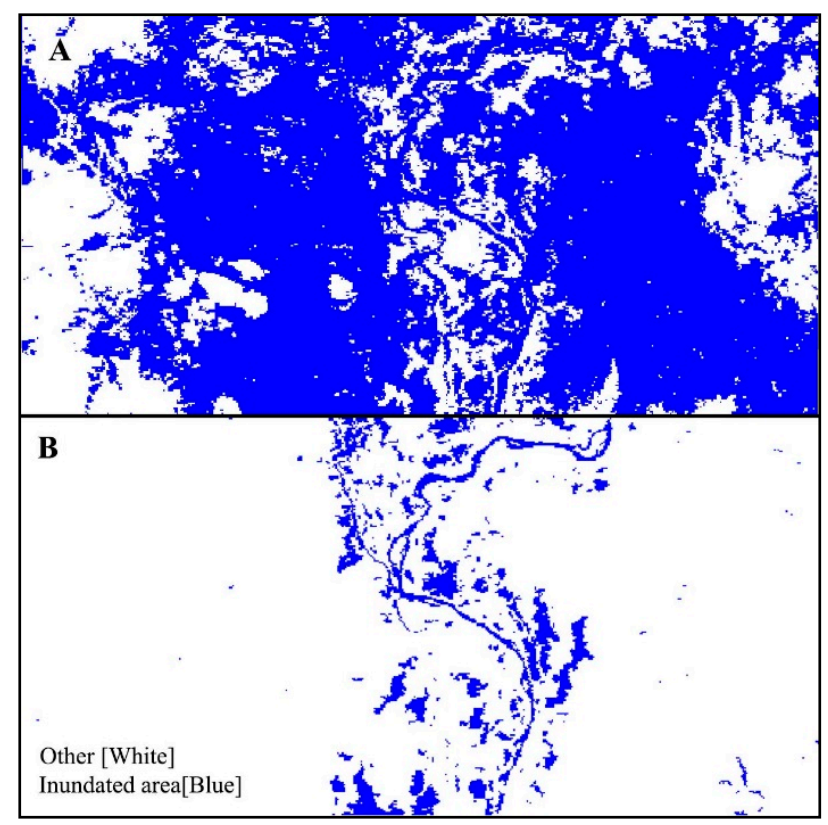

Figure 4. Inundated (water surface) area derived from (A) original WFFI and (B) modified WFFI on 1 January 2002.

\subsection{Temporal Characteristics of Annual Floods and Water Levels}

Using the estimated inundation maps from the modified WFFI, the spatial distributions of the start and end dates of annual floods were computed (Figure 5). The spatial distribution of the start and end flood dates varied year by year. Furthermore, seasonal changes in the extent of the estimated flood area were calculated for each year (Figure 6). The estimated start date of the flood indicated that flood occurrence was late from 2010 to 2013. Moreover, the estimated flood inundation area showed $27 \%$ decrease over the last few years.

Water infrastructure developments, such as flood control, dam hydropower, and irrigation, were the main causes of reduced inundation area [33]. At the same time, the gradient of the water level at five stations in the rainy season exhibited a negative trend. Figure 7 shows the water levels at the Bassac Chamtomuk station in the rainy season. The water level showed decreased trends over the past 12 years (2002-2013). There are many water infrastructure plans in the upstream river, especially hydropower dams (Osborne 2008; Pearse-Smith 2012). Similarly, Arias et al. [34] found that water infrastructure development was expected to shrink the magnitude of floods by raising the water level during the dry season and reducing it during the rainy season. These developments resulted from the amount of water used and the demand increase due to economic development, especially hydropower dam construction upstream. Nik Hashim [35] noted that dam construction and water demands led to a $4 \%$ decrease in the maximum water level in the rainy season and a catchment area decline of $5 \%$ in the Tonle Sap region. This negative impact would lead to decreased fish production and thereby threats to food security, restricted agriculture productivity from reduced water supply for agriculture land, water pollution that is harmful to the livelihoods of local communities, and ecological changes, especially in aquatic ecosystems, and environmental changes that will also affect economic development [36]. 

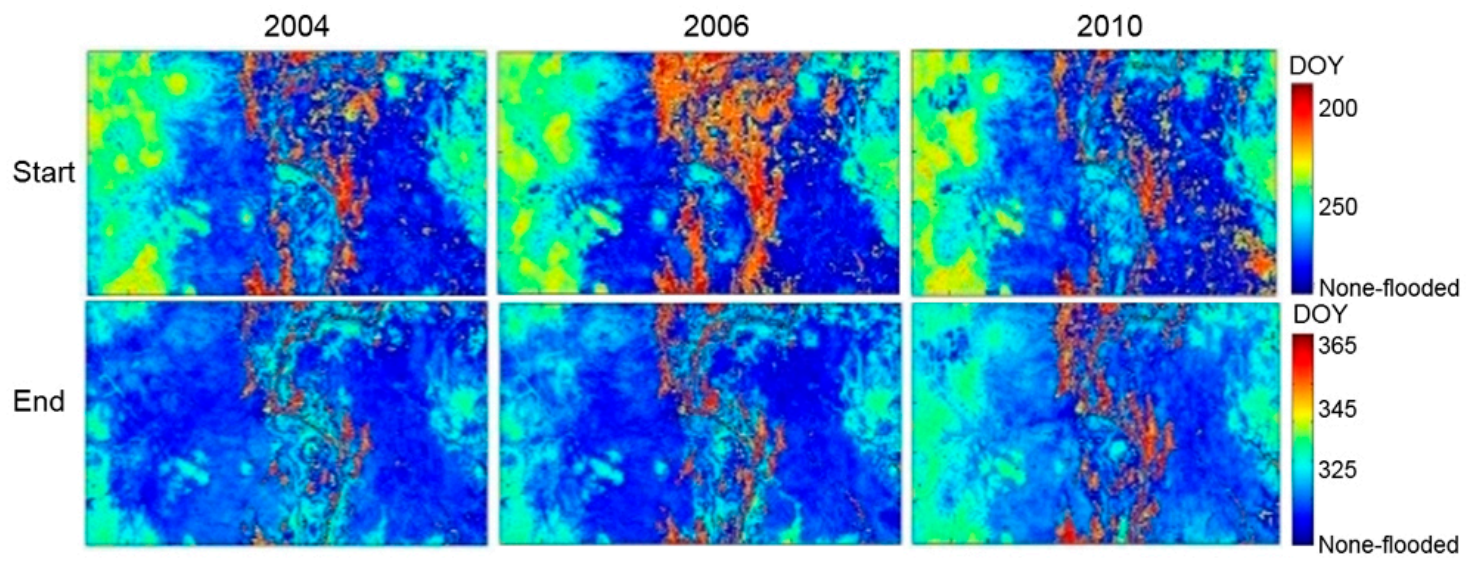

Figure 5. Spatial distribution maps of start/end dates (day of year (DOY)) of flooding in 2004, 2006 and 2010 using modified WFFI with MODIS data.

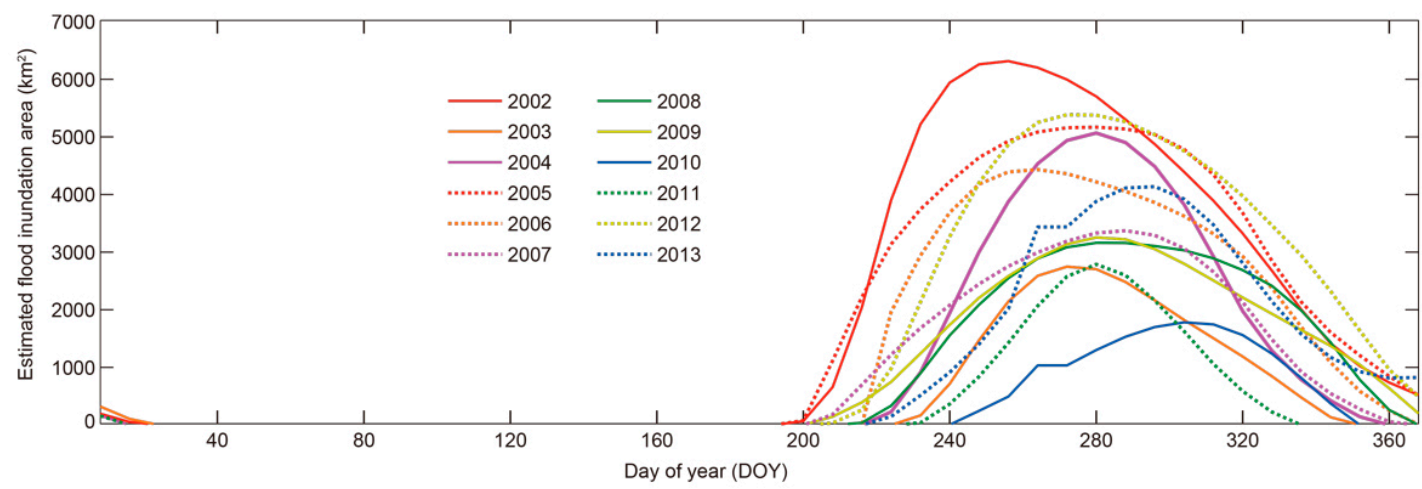

Figure 6. Seasonal changes in the extent of the estimated area of flood pixels with the method proposed.

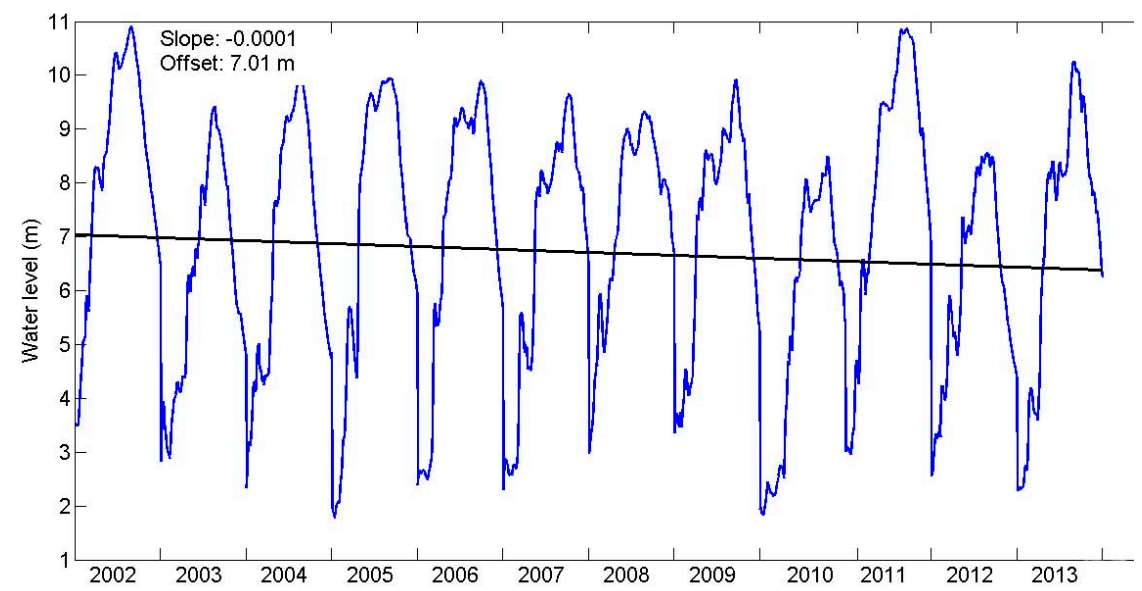

Figure 7. Water level trend at the Bassac Chamtomuk station during the rainy season (June to November).

\subsection{Land Cover and Water Body Changes between 2002 and 2012}

Based on the MCD12Q1 product, Table 2 summarizes the land cover change between 2002 and 2012. The area of water, forest, grassland and permanent wetland decreased from 1686.3, 2570.3, 2468.5 and $790.8 \mathrm{~km}^{2}$ in 2002 to $919.8,2195.8,1602$ and $435.8 \mathrm{~km}^{2}$ in 2012, respectively. The area of croplands increased $11.7 \%$ from $20,138.0 \mathrm{~km}^{2}$ in 2002 to $22,498.8 \mathrm{~km}^{2}$ in 2012 . By applying the change detection method, it is evident that most of the permanent water bodies have been converted to permanent wetlands and croplands. 
The expansion of agricultural land is one of the reasons for decreasing water area. Senevirathne et al. [37] also found that water bodies significantly decreased due to increase croplands and built up areas in Cambodia.

However, the increasing trend of cropland area may be closely linked to economic growth in Cambodia. Agriculture is one of the main sectors contributing to economic growth, and the expansion of agricultural land would lead to an increase in productivity, which would contribute to national food security and the alleviation of poverty [38]. The consistent trends in the estimated flood area and the decrease in the permanent water body land cover might be caused by hydropower dams, which take water for electricity generation, and other water uses fueling economic growth, such as industry and irrigation for agriculture $[39,40]$.

Table 2. Land cover change between 2002 and 2012 from MCD12Q1 product.

\begin{tabular}{ccccccc}
\hline \multirow{2}{*}{ Year } & \multicolumn{5}{c}{ Land Cover Area $\mathbf{( k m}^{\mathbf{2}}$ ) and the Percent (\%) Ratio since 2002 } \\
\cline { 2 - 7 } & Water & Forest & Grassland & Permanent Wetland & Urban & Cropland \\
\hline \multirow{2}{*}{2002} & 1686.3 & 2570.3 & 2468.5 & 790.8 & 135.3 & $20,138.0$ \\
& $(100)$ & $(100)$ & $(100)$ & $(100)$ & $(100)$ & $(100)$ \\
2003 & 1520.0 & 2516.5 & 2215.8 & 763.3 & 135.5 & $20,638.0$ \\
& $(90.1)$ & $(97.9)$ & $(89.8)$ & $(96.5)$ & $(100.2)$ & $(102.5)$ \\
2004 & 1211.0 & 2157.3 & 2211.3 & 545.8 & 136.3 & $21,527.5$ \\
& $(71.8)$ & $(83.9)$ & $(89.6)$ & $(69.0)$ & $(100.7)$ & $(106.9)$ \\
2005 & 488.0 & 2353.3 & 2220.0 & 236.0 & 137.0 & $21,527.5$ \\
& $(28.9)$ & $(91.6)$ & $(89.9)$ & $(29.8)$ & $(101.3)$ & $(106.9)$ \\
2006 & 706.8 & 2189.3 & 2080.5 & 462.3 & 136.5 & $22,249.8$ \\
& $(41.9)$ & $(85.2)$ & $(84.3)$ & $(58.5)$ & $(100.9)$ & $(110.5)$ \\
2007 & 650.8 & 2076.8 & 2144.8 & 411.5 & 136.8 & $22,368.5$ \\
& $(38.6)$ & $(80.8)$ & $(86.9)$ & $(52.0)$ & $(101.1)$ & $(111.1)$ \\
2008 & 744.5 & 2076.8 & 2144.8 & 659.0 & 135.8 & $22,071.8$ \\
& $(44.2)$ & $(80.8)$ & $(86.9)$ & $(83.3)$ & $(100.4)$ & $(109.6)$ \\
2009 & 633.5 & 2054.3 & 2076.8 & 690.5 & 136.3 & $22,194.8$ \\
& $(37.6)$ & $(79.9)$ & $(84.1)$ & $(87.3)$ & $(100.7)$ & $(110.2)$ \\
2010 & 594.8 & 2142.5 & 2123.0 & 574.3 & 136.5 & $22,218.0$ \\
& $(35.3)$ & $(83.4)$ & $(86.0)$ & $(72.6)$ & $(100.9)$ & $(110.3)$ \\
2011 & 1082.5 & 2082.3 & 1723.5 & 680.5 & 136.0 & $22,084.3$ \\
& $(64.2)$ & $(81.0)$ & $(69.8)$ & $(86.1)$ & $(100.6)$ & $(109.7)$ \\
2012 & 919.8 & 2195.8 & 1602.0 & 435.8 & 137.0 & $22,498.8$ \\
& $(54.5)$ & $(85.4)$ & $(64.9)$ & $(55.1)$ & $(101.3)$ & $(111.7)$ \\
\hline
\end{tabular}

\section{Conclusions}

This study investigated spatio-temporal flood inundation and land cover change in the southern part of Cambodia using the Terra MODIS products. The WFFI algorithm for flood inundation detection was used in this research, and the parameters were modified to fit with the current study. The flood inundation maps from MODIS $500 \mathrm{~m}$ resolution were evaluated by comparing them with flood inundation maps based on resampled Landsat data. In a comparison between the original and modified WFFIs, the modified WFFI (70-96\%) showed better accuracy than the original WFFI (30-70\%). This demonstrates that the modified WFFI methodology is very useful for detecting flood inundation and that the flood inundation maps from MODIS images can be used to characterize flooding, which is very useful for the integration of water resources, flood management and the maintenance of wetland ecosystems. Overall, the WFFI products are in good agreement with the water surface area derived from Landsat images and hydrological data in terms of temporal change and spatial distribution. Furthermore, the estimated flood inundation data exhibited a significant delay since 2008 caused by climate change. Based on the yearly land cover data, the permanent water body and wetland areas decreased, while the cropland areas increased. This was a result of increased agricultural productivity. 
However, water shortage is one of the major obstacles to increasing agricultural productivity, and it also has a negative impact on aquatic ecology such as fish spawning grounds.

Author Contributions: Conceptualization, N.V. and K.K.; data curation, N.V.; formal analysis, N.V., D.P.T., N.V.O., Z.G. and J.L.; investigation, N.V.; methodology, K.K., D.P.T., N.V.O., Z.G. and J.L.; project administration, K.K.; resources, S.K. and C.B.; supervision, K.K.; writing-original draft, N.V. and K.K.; writing-review and editing, D.P.T., N.V.O., Z.G., J.L., S.K. and C.B.

Funding: This work was partially supported by the Hiroshima Earth Environment Information Center for the paper submission and the Japanese Grant Aid for Human Resource Development Scholarship (JDS) and the Japan International Cooperation Agency (JICA) for financial support to the first author (N.V.) for the field survey in Cambodia.

Acknowledgments: We are grateful to all the members of the Grassland Science Laboratory, Graduate School for International Development and Cooperation (IDEC), Hiroshima University, Japan, for their valuable comments on this manuscript.

Conflicts of Interest: The authors declare no conflict of interest.

\section{References}

1. Cambodia, R.G. Post-Flood Early Recovery Need Assessment Report; United Nations Development Programme (UNDP): Phnom Penh, Cambodia, 2014.

2. Oh, M.W.; Komatsu, S. Characterization of proteins in soybean roots under flooding and drought stresses. J. Proteomics 2015, 114, 161-181. [CrossRef] [PubMed]

3. Kamal, A.H.M.; Rashid, H.; Sakata, K.; Komatsu, S. Gel-free quantitative proteomic approach to identify cotyledon proteins in soybean under flooding stress. J. Proteomics 2015, 112, 1-13. [CrossRef]

4. Asada, H.; Matsumoto, J.; Rahman, R. Impact of recent severe floods on rice production in Bangladesh. Geogr. Rev. Jpn. 2005, 78, 783-793. [CrossRef]

5. Junk, W.J.; Bayley, P.B.; Sparks, R.E. The flood pulse concept in river-floodplain-systems. Can. J. Fish. Aquat. Sci. 1989, 106, 110-127.

6. Seiler, R.; Schmidt, J.; Diallo, O.; Csaplovics, E. Flood monitoring in a semi-arid environment using spatially high resolution radar and optical data. J. Environ. Manage. 2009, 90, 2121-2129. [CrossRef]

7. Mallinis, G.; Gitas, I.Z.; Giannakopoulos, V.; Maris, F.; Tsakiri-Strati, M. An object-based approach for flood area delineation in a transboundary area using ENVISAT ASAR and LANDSAT TM data. Int. J. Digit. Earth 2013, 6, 124-136. [CrossRef]

8. Henry, J.B.; Chastanet, P.; Fellah, K.; Desnos, Y.L. Envisat multi-polarized ASAR data for flood mapping. Int. J. Remote Sens. 2006, 27, 1921-1929. [CrossRef]

9. Evans, T.L.; Costa, M.; Telmer, K.; Silva, T.S.F. Using ALOS/PALSAR and RADARSAT-2 to Map Land Cover and Seasonal Inundation in the Brazilian Pantanal. IEEE J. Sel. Top. Appl. Earth Obs. Remote Sens. 2010, 3, 560-575. [CrossRef]

10. Xiao, X.; Boles, S.; Frolking, S.; Salas, W.; Moore, B.; Li, C.; He, L.; Zhao, R. Observation of flooding and rice transplanting of paddy rice fields at the site to landscape scales in China using VEGETATION sensor data. Int. J. Remote Sens. 2002, 23, 3009-3022. [CrossRef]

11. Dao, P.D.; Liou, Y.A. Object-based flood mapping and affected rice field estimation with landsat 8 OLI and MODIS data. Remote Sens. 2015, 7, 5077-5097. [CrossRef]

12. Sakamoto, T.; Cao, P.V.; Nguyen, N.V.; Kotera, A.; Yokozawa, M. Agro-ecological interpretation of rice cropping systems in flood-prone areas using MODIS imagery. Photogramm. Eng. Remote Sensing 2009, 75, 413-424. [CrossRef]

13. Sakamoto, T.; Van Nguyen, N.; Ohno, H.; Ishitsuka, N.; Yokozawa, M. Spatio-temporal distribution of rice phenology and cropping systems in the Mekong Delta with special reference to the seasonal water flow of the Mekong and Bassac rivers. Remote Sens. Environ. 2006, 100, 1-16. [CrossRef]

14. Sakamoto, T.; Van Phung, C.; Kotera, A.; Nguyen, K.D.; Yokozawa, M. Analysis of rapid expansion of inland aquaculture and triple rice-cropping areas in a coastal area of the Vietnamese Mekong Delta using MODIS time-series imagery. Landsc. Urban Plan. 2009, 92, 34-46. [CrossRef]

15. Valavanis, V.D.; Pierce, G.J.; Zuur, A.F.; Palialexis, A.; Saveliev, A.; Katara, I.; Wang, J. Modelling of essential fish habitat based on remote sensing, spatial analysis and GIS. Hydrobiologia 2008, 612, 5-20. [CrossRef] 
16. Sakamoto, T.; Van Nguyen, N.; Kotera, A.; Ohno, H.; Ishitsuka, N.; Yokozawa, M. Detecting temporal changes in the extent of annual flooding within the Cambodia and the Vietnamese Mekong Delta from MODIS time-series imagery. Remote Sens. Environ. 2007, 109, 295-313. [CrossRef]

17. Islam, A.S.; Bala, S.K.; Haque, M.A. Flood inundation map of Bangladesh using MODIS time-series images. J. Flood Risk Manag. 2010, 3, 210-222. [CrossRef]

18. Doyle, C. City of Water: Architecture, Infrastructure and the Floods of Phnom Penh. Available online: https://www.academia.edu/2502352/City_of_Water_Architecture_Urbanism_and_the_ Floods_of_Phnom_Penh (accessed on 20 April 2019).

19. Dwyer, J.; Schmidt, G. The MODIS Reprojection Tool. In Earth Science Satellite Remote Sensing; Qu, J.J., Gao, W., Kafatos, M., Murphy, R.E., Salomonson, V.V., Eds.; Springer: Berlin/Heidelberg, Germany, 2007; pp. 162-177, ISBN 978-3-540-37294-3.

20. Herrmann, H.; Bucksch, H. Global Land Cover Facility. Available online: http://www.landcover.org/ (accessed on 20 April 2019).

21. Hui, F.; Xu, B.; Huang, H.; Yu, Q.; Gong, P. Modelling spatial-temporal change of Poyang Lake using multitemporal Landsat imagery. Int. J. Remote Sens. 2008, 29, 5767-5784. [CrossRef]

22. Jain, S.K.; Singh, R.D.; Jain, M.K.; Lohani, A.K. Delineation of flood-prone areas using remote sensing techniques. Water Resour. Manag. 2005, 19, 333-347. [CrossRef]

23. Ordoyne, C.; Friedl, M.A. Using MODIS data to characterize seasonal inundation patterns in the Florida Everglades. Remote Sens. Environ. 2008, 112, 4107-4119. [CrossRef]

24. Ouma, Y.; Tateishi, R. A water index for rapid mapping of shoreline changes of five East African Rift Valley lakes: An empirical analysis using Landsat TM and ETM+ data. Int. J. Remote Sens. 2006, 27, 3153-3181. [CrossRef]

25. $\mathrm{Xu}, \mathrm{H}$. Modification of normalised difference water index (NDWI) to enhance open water features in remotely sensed imagery. Int. J. Remote Sens. 2006, 27, 3025-3033. [CrossRef]

26. Ticehurst, C.; Guerschman, J.P.; Chen, Y. The strengths and limitations in using the daily MODIS open water likelihood algorithm for identifying flood events. Remote Sens. 2014, 6, 11791-11809. [CrossRef]

27. Ji, L.; Zhang, L.; Wylie, B. Analysis of Dynamic Thresholds for the Normalized Difference Water Index. Photogramm. Eng. Remote Sens. 2013, 75, 1307-1317. [CrossRef]

28. Du, Y.; Zhang, Y.; Ling, F.; Wang, Q.; Li, W.; Li, X. Water bodies' mapping from Sentinel-2 imagery with Modified Normalized Difference Water Index at 10-m spatial resolution produced by sharpening the swir band. Remote Sens. 2016, 8, 354. [CrossRef]

29. Ryu, J.-H.; Won, J.-S.; Min, K.D. Waterline Extraction from Landsat TM Data in a Tidal Flat: A Case Study in Gomso Bay, Korea. Remote Sens. Environ. 2002, 83, 442.

30. Frazier, P.S.; Page, K.J. Water body detection and delineation with Landsat TM data. Photogramm. Eng. Remote Sens. 2000, 66, 1461-1467.

31. Ogilvie, A.; Belaud, G.; Delenne, C.; Bailly, J.-S.; Bader, J.-C.; Oleksiak, A.; Ferry, L.; Martin, D. Decadal monitoring of the Niger Inner Delta flood dynamics using MODIS optical data. J. Hydrol. 2015, 523, 368-383. [CrossRef]

32. McFeeters, S.K. The use of the Normalized Difference Water Index (NDWI) in the delineation of open water features. Int. J. Remote Sens. 1996, 17, 1425-1432. [CrossRef]

33. Hagiwara, T.; Kazama, S.; Sawamoto, M. Relationship Between Inundation Area and Irrigation Area on Flood Control in the Lower Mekong. In Advances in Hydraulics and Water Engineering; World Scientific Publishing Company: Singapore, 2010; Volume 1, pp. 590-595.

34. Arias, M.E.; Cochrane, T.A.; Piman, T.; Kummu, M.; Caruso, B.S.; Killeen, T.J. Quantifying changes in flooding and habitats in the Tonle Sap Lake (Cambodia) caused by water infrastructure development and climate change in the Mekong Basin. J. Environ. Manage. 2012, 112, 53-66. [CrossRef]

35. Tada, M.; Huang, W.; Kobayashi, S.; Tanji, H. Water resource exploitation of the Mekong river basin and the influences on the inland fisheries of Cambodia. In Proceedings of the Fourteenth Biennial Conference of the International Institute of Fisheries Economics \& Trade, Nha Trang, Vietnam, 22-25 July 2008.

36. Pearse-Smith, S.W.D. The Impact of Continued Mekong Basin Hydropower Development on Local Livelihoods. Cons. J. Sustain. Dev. 2012, 7, 62-75. [CrossRef] 
37. Senevirathne, N.; Mony, K.; Samarakoon, L.; Hazarika, M.K. Land Use/Land Cover Change Detection of Tonle Sap Watershed, Cambodia. In Proceedings of the 31st Asian Conference on Remote Sensing, Hanoi, Vietnam, 1-5 November 2014.

38. Bansok, R.; Phirun, N.; Chhun, C. Development and Climate Change Project: The Case of Cambodia; CDRI Working Paper Series; Cambodia Development Resource Institute (CDRI): Phnom Penh, Cambodia, 2011.

39. Chinvanno, S. Information for sustainable development in light of climate change in Mekong River Basin. Southeast Asia START Reg. Cent. Bangkok Thail. 2004, 108-115.

40. Eastham, J.; Mpelasoka, F.; Ticehurst, C.; Dyce, P.; Ali, R.; Kirby, M. Mekong River Basin Water Resources Assessment: Impacts of Climate Change. Csiro 2008, 153.

C 2019 by the authors. Licensee MDPI, Basel, Switzerland. This article is an open access article distributed under the terms and conditions of the Creative Commons Attribution (CC BY) license (http://creativecommons.org/licenses/by/4.0/). 